\title{
Geographic Variation of Mercury in Breeding Tidal Marsh Sparrows of the Northeastern United States
}

\section{Christopher J. Sayers ( $\nabla$ cjs347@cornell.edu )}

Cornell University College of Agriculture and Life Sciences https://orcid.org/0000-0002-7394-3929

\section{Mackenzie R. Roeder}

The University of Maine

\section{Lindsay Forrette}

University of New England

\section{Daniel Roche}

West Virginia University

\section{Gaetan L.B. Dupont}

University of Massachusetts Amherst

\section{Sam E. Apgar}

University of Connecticut

\section{Alison R. Kocek}

SUNY-ESF: SUNY College of Environmental Science and Forestry

\section{Alexandra M. Cook}

SUNY-ESF: SUNY College of Environmental Science and Forestry

\section{W. Gregory Shriver}

University of Delaware

\section{Chris S. Elphick}

University of Connecticut

\section{Brian Olsen}

The University of Maine

\section{David N. Bonter}

Cornell Lab of Ornithology: Cornell University Cornell Laboratory of Ornithology

\section{Research Article}

Keywords: Ammospiza caudacuta, Ammospiza maritima maritima, bioindicator, estuary, mercury, salt marsh

Posted Date: March 17th, 2021

DOI: https://doi.org/10.21203/rs.3.rs-304341/v1 
License: (c) (i) This work is licensed under a Creative Commons Attribution 4.0 International License. Read Full License

Version of Record: A version of this preprint was published at Ecotoxicology on August 12th, 2021. See the published version at https://doi.org/10.1007/s10646-021-02461-y. 


\title{
Geographic variation of mercury in breeding tidal marsh sparrows of the northeastern United States
}

\author{
Christopher J. Sayers II 1,2* (https://orcid.org/0000-0002-7394-3929), Mackenzie R. Roeder ${ }^{3}$ \\ (https://orcid.org/0000-0002-5169-5397), Lindsay Forrette ${ }^{4}$ \\ (https://orcid.org/0000-0002-2187-3105), Daniel Roche ${ }^{5}$, Gaetan L. B. Dupont ${ }^{6}$ \\ (https://orcid.org/0000-0003-1175-0694), Sam E. Apgar ${ }^{7}$, Alison R. Kocek ${ }^{8}$ \\ (https://orcid.org/0000-0001-5780-7065), Alexandra M. Cook ${ }^{8}$, W. Gregory Shriver ${ }^{9}$ \\ (https://orcid.org/0000-0003-0911-8462), Chris S. Elphick ${ }^{7}$, Brian Olsen ${ }^{3}$ \\ (https://orcid.org/0000-0001-5608-2779), David N. Bonter ${ }^{1,2}$ \\ (https://orcid.org/0000-0003-1768-1941)
}

${ }^{1}$ Department of Natural Resources \& the Environment, Cornell University, Ithaca, NY 14850 ${ }^{2}$ Cornell Lab of Ornithology, Ithaca, NY 14850

${ }^{3}$ School of Biology and Ecology, University of Maine, Orono, ME 04469

${ }^{4}$ School of Marine Programs, University of New England, Biddeford, ME 04005

${ }^{5}$ Division of Forestry and Natural Resources, Wildlife and Fisheries Resources Program, West Virginia University, Morgantown, WV 26501

${ }^{6}$ Department of Organismic and Evolutionary Biology, University of Massachusetts Amherst, Amherst, MA 01003

${ }^{7}$ Department of Ecology \& Environmental Biology and Center of Biological Risk, University of Connecticut, Storrs, CT 06269

${ }^{8}$ Department of Environmental and Forest Biology, State University of New York College of Environmental Science and Forestry, Syracuse, NY 13210

${ }^{9}$ Department of Entomology and Wildlife Ecology, University of Delaware, Newark, DE 19716

"Corresponding author. Email: cjs347@cornell.edu.

\begin{abstract}
Saltmarsh sparrows (Ammospiza caudacuta) and seaside sparrows (A. maritima) are species of conservation concern primarily due to global sea-level rise and habitat degradation. Environmental mercury $(\mathrm{Hg})$ contamination may present additional threats to their reproductive success and survival. To assess site-specific total mercury ( $\mathrm{THg}$ ) exposure and identify environmental correlates of $\mathrm{THg}$ detection across a large portion of the breeding range where these species co-occur, we sampled blood from adult male saltmarsh and seaside sparrows at 27 marsh sites from Maine to Virginia, USA. The mean THg concentration ( \pm 1 SD) throughout the entire sampling range was $0.531 \pm 0.287 \mu \mathrm{g} / \mathrm{g}$ wet weight (ww) for saltmarsh sparrows and 0.442 $\pm 0.316 \mu \mathrm{g} / \mathrm{g}$ ww for seaside sparrows. Individual THg concentrations ranged from $0.135-1.420$ $\mu \mathrm{g} / \mathrm{g}$ ww for saltmarsh sparrows and $0.153-1.530 \mu \mathrm{g} / \mathrm{g}$ ww for seaside sparrows. Model averaging from a suite of linear mixed models supported species-based differences in blood THg. On average, saltmarsh sparrows had $20.1 \%$ higher blood THg concentrations than seaside sparrows. We hypothesize that species-specific THg concentrations are influenced by differences in diet or foraging preferences between these species. We did not detect any correlations between sparrow THg concentrations and land cover characteristics surrounding sampled marshes or cumulative average annual precipitation.
\end{abstract}


Key Words: Ammospiza caudacuta, Ammospiza maritima maritima, bioindicator, estuary, mercury, salt marsh

\section{Declarations}

Funding: This work was supported by the M. Savoca \& L. Orrok Undergraduate Research Endowment at the Cornell Lab of Ornithology; Ann S. \& Robert R. Morley Student Research Grant at Cornell University; NSF EPSCoR Track-2 Award \#1826777; National Fish and Wildlife Foundation and US Fish and Wildlife Service Award \#F18AC00046.

Conflicts of interest: The authors declare that they have no conflict of interest.

Ethics approval (include appropriate approvals or waivers): Sampling was conducted under approved animal care protocols from the State University of New York: College of Environmental Science and Forestry (180201), University of Connecticut (A17-011), and University of Maine (A2018-03-03).

Consent to participate (include appropriate statements): Not applicable.

Consent for publication (include appropriate statements): Not applicable.

Availability of data and material/ code availability: All data and software are archived and available at https://github.com/csayers2/Sayers-Ammospiza-Hg-2021 or https://www.mrlc.gov/data.

Authors' contributions: Christopher J. Sayers II and David N. Bonter contributed to the study conception and design. Material preparation and data collection were performed by Christopher J. Sayers II, Mackenzie R. Roeder, Lindsay Forrette, Daniel Roche, Sam E. Apgar, Alison R. Kocek, Alexandra M. Cook, W. Gregory Shriver, Chris S. Elphick, Brian Olsen, and David N. Bonter. Christopher J. Sayers II, Gaetan L. B. Dupont, David N. Bonter, and Chris S. Elphick conducted and contributed to analyses. The first draft of the manuscript was written by Christopher J. Sayers II and all authors commented on previous versions of the manuscript. All authors read and approved the final manuscript.

\section{Acknowledgements}

We would like to thank Jennifer Walsh for facilitating contacts, Elizabeth Tymkiw for providing logistical details for site access, Robert Taylor for sample analysis, Sara Kaiser, Darin McNeil, and Wesley Hochachka for advice on statistical analysis, and Sarah Dzielski for providing relevant literature. We thank Isaac Kozukhin, Cory Ross, and Sarah Biesemier for field assistance. 


\section{Introduction}

Mercury $(\mathrm{Hg})$ is a widespread environmental contaminant that can pose a threat to wildlife by affecting neurological and reproductive systems (Evers 2018). Common anthropogenic sources of inorganic $\mathrm{Hg}$ include coal-fired power plants, waste incinerators, chlorine and metal processing plants, landfills, and artisanal and small-scale gold mines that emit $\mathrm{Hg}$ into the atmosphere or directly into waterways (UNEP 2019). Once deposited into aquatic systems, either by atmospheric processes or leachate, inorganic $\mathrm{Hg}$ can be converted into the neurotoxic and bioavailable methylmercury (MeHg). Generally, organisms that occupy higher trophic levels are disproportionately affected by $\mathrm{MeHg}$ because it is lipophilic and migrates through food webs via biomagnification (Evers et al. 2005). Increased concentrations of $\mathrm{MeHg}$ in tissue samples of piscivorous and insectivorous birds are associated with impaired coordination, foraging apathy, reduced reproductive success, and reduced survivorship (Scheuhammer 1987; Bouton et al. 1999; Evers et al. 2008).

In anoxic aquatic sediments, sulfate-reducing bacteria accelerate the production of $\mathrm{MeHg}$ (Compeau and Bartha 1985), leading to elevated risks for organisms living in, around, or feeding from contaminated wetlands. Both the saltmarsh sparrow (Ammospiza caudacuta) and seaside sparrow (A. maritima) are tidal marsh specialists and spend their entire life cycles within saltmarsh habitats, where risk of exposure to $\mathrm{MeHg}$ can be elevated. Being dependent on salt marshes, which are under increasing threat of degradation and loss, tidal marsh sparrows are species of high conservation concern (Rosenberg et al. 2016). Anthropogenic activities including coastal development, marsh fragmentation, and alteration of hydrology have all reduced habitat available for both saltmarsh and seaside sparrows (Greenlaw et al. 2020; Post and Greenlaw 
2020), and global sea-level rise threatens saltmarsh systems range-wide (Bayard and Elphick 2011; Field et al. 2017; Greenlaw et al. 2020; Post and Greenlaw 2020). The saltmarsh sparrow is considered "globally endangered" by the International Union for Conservation of Nature in response to rapid population declines (Birdlife International 2018), decreasing at 9\% per year with over 70\% of the global population lost since the 1990s (Correll et al. 2017; Roberts et al. 2019). Sea-level rise and increased tidal flooding risk are the major drivers of population loss for this species, as approximately $60 \%$ of all nest failures occur due to flooding events (Shriver et al. 2007; Gjerdrum et al. 2008), and are projected to cause extinction as early as 2035 (Field et al. 2017, 2018; Roberts et al. 2019). Because salt marshes and coastal estuaries are often impacted by polluted urbanized watershed runoff (Schwarzbach et al. 2006), heavy metal contamination may present additional challenges to sparrow reproductive success and survival.

Tidal marsh sparrows can be effective bioindicators for MeHg contamination of saltmarsh systems, and for quantifying the potential threat that MeHg poses to marsh bird populations, at a variety of geographic scales (Shriver et al. 2006; Warner et al. 2010; Lane et al. 2011, 2020; Winder 2012; Ruskin et al. In prep.). In all prior research, tidal marsh sparrow blood Hg levels have approached or exceeded $0.7 \mu \mathrm{g} / \mathrm{g}$ wet weight (Shriver et al. 2006; Lane et al. 2011, 2020; Warner et al. 2010; Winder 2012; Ruskin et al. In prep.), a level that has been shown to influence nesting success in Carolina Wren (Thryothorus ludovicianus) (Jackson et al. 2011). Though atmospheric deposition of $\mathrm{Hg}$ via precipitation is known to account for a sizeable portion of the $\mathrm{Hg}$ present in the environment (Hudson et al. 1995), breeding tidal marsh sparrow $\mathrm{Hg}$ concentrations in the northeastern US vary significantly by site (Warner et al. 2010; Lane et al. 2011, 2020; Ruskin et al. In prep.) without any consistent temporal trends (Lane et al. 2020). 
These findings suggest that regional atmospheric deposition alone does not drive $\mathrm{Hg}$ bioavailability in coastal wetlands of the northeastern USA. Rather, variation in tidal marsh sparrow $\mathrm{Hg}$ levels among marsh sites is more likely due to site-specific MeHg production rates, differences in marsh hydrodynamics or biogeochemistry, differences in local food webs and food availability, or nearby point sources of the pollutant and surrounding land use (Lane et al. 2011, 2020).

Little is known about the dynamics of $\mathrm{Hg}$ in tidal wetlands or how local land cover influences $\mathrm{Hg}$ levels. Wetland-associated dissolved organic carbon (DOC) is positively correlated with the presence, production, and export of MeHg in the hydrological system (St. Louis et al. 1994; Krabbenhoft et al. 1995; Driscoll et al. 1995, 1998; Wiener and Shields 2000). Trees absorb atmospheric $\mathrm{Hg}$ through leaf stomata and may deposit $\mathrm{Hg}$ into terrestrial and aquatic systems during litterfall, or enhance the $\mathrm{Hg}$ concentration of precipitation as it falls through the canopy (Rea et al. 1996). Sources of direct Hg discharges, such as metal-processing plants, landfills, and waste-water treatment plants, tend to aggregate in urbanized environments and are linked to Hg contamination within drainage basins (Niebla et al. 1976; Hildebrand et al. 1980; Gilmour and Bloom 1995). Impervious surfaces also direct Hg to surface water via storm water drainage systems (Rule et al. 2006). Therefore, we predicted that MeHg levels in marshes and marsh-associated birds would be affected by the relative amount of wetlands, forests, and developed areas in the surrounding landscape.

Range-wide analyses of $\mathrm{Hg}$ contamination are lacking for most species, including saltmarsh and seaside sparrows. Within their co-occurring breeding ranges, three major geographic gaps in Hg sampling exist: coastal New Jersey, coastal Delmarva, and the eastern 
Chesapeake Bay. These subregions collectively support over $65 \%$ of both the global saltmarsh sparrow population and the northeastern seaside sparrow (A. m. maritima) population (Wiest et al. 2016). Consequently, the objectives of our study were to, 1) quantify regional variation in the mercury detected in saltmarsh and seaside sparrows across a large portion of their breeding ranges in the northeastern USA, and 2) identify environmental and spatial characteristics that influence patterns of mercury detection. We sought to conduct an assessment of local mercury contamination, which could potentially inform conservation and remediation efforts.

\section{Methods}

\section{Sample collection}

To quantify regional variation of $\mathrm{MeHg}$ exposure in saltmarsh and seaside sparrows, we collected blood samples from 67 adult male saltmarsh sparrows and 53 adult male seaside sparrows at 27 marsh sites along the coast of the northeastern and mid-Atlantic USA from June 1 to July 31, 2018. Marsh sites were located from Maine south to the Delmarva Peninsula of Virginia (Fig. 1, Table 1) and were selected using a randomization process that first used generalized random tessellation stratified sampling to generate bird survey points (Wiest et al. 2016). Points were then randomly subsampled after stratifying by sparrow abundance (see "Rapid Demo SOP," www.tidalmarshbirds.org). Because blood samples are indicative of days to weeks of dietary exposure (Evers 2018) and reliably represent site-specific MeHg availability, they are an appropriate sampling tissue to understand tidal marsh sparrow exposure to $\mathrm{MeHg}$ in the local environment (Evers et al. 2005; Shriver et al. 2006). Tidal marsh sparrows begin their prebasic molt in mid- to late August (Greenlaw et al. 2020; Post and Greenlaw 2020); therefore, 
sampling during June and July removes the confounding possibility of birds shunting their MeHg load into feathers during molt. We only sampled adult males to avoid the potential confounding factors associated with females passing on their Hg body burden to eggs during the laying period (Brasso et al. 2010; Ackerman et al. 2013; Ou et al. 2015).

Sparrows were captured within a $50 \mathrm{~m}$ radius of a given site using mist nets and fitted with an aluminum US Fish and Wildlife Service leg band. Individuals identified as after-hatch-year males via a cloacal protuberance were weighed using a digital scale, and then $10-50 \mu \mathrm{L}$ of blood were collected in $70 \mu \mathrm{L}$ heparinized capillary tubes using brachial venipuncture. Capillary tubes were immediately sealed at both ends using Leica Microsystems Critocaps $^{\mathrm{TM}}$, placed into a Vacuette ${ }^{\mathrm{TM}}$, and stored in a cooler with ice packs. Samples were transferred into a freezer within 8 hours and were maintained below $-4{ }^{\circ} \mathrm{C}$ until analysis.

\section{Laboratory analysis}

Blood samples were analyzed for total $\mathrm{Hg}(\mathrm{THg})$, the combination of methylated and unmethylated Hg in the blood, at the Texas A\&M University Trace Element Research Laboratory in College Station, Texas using a combustion, gold trapping, atomic absorption spectroscopy approach. This analysis was performed using a Nippon MA-3000 direct thermal decomposition $\mathrm{Hg}$ analyzer equipped with dual cell detectors. THg was analyzed instead of MeHg because Rimmer et al. (2005) showed that the total Hg in songbird blood is composed of approximately $95 \% \mathrm{MeHg}$. Samples were thawed, removed from capillary tubes, weighed to the nearest $0.01 \mathrm{mg}$, transferred to pre-combusted cuvettes, and then placed into the Nippon MA-3000's autosampler. Samples were dried and combusted under a constant flow of $\mathrm{O}_{2}$, 
combustion gases were passed through a gold trap to remove $\mathrm{Hg}$ gas from the combustion stream, and the gold trap was then heated to release concentrated $\mathrm{Hg}^{0}$ to be swept into two atomic absorption cells. THg concentrations in samples were quantified by comparing absorption peaks with known calibration standards. Instrument calibration was performed using a blank and three calibration standards in both detector cells and verified every 10 samples using two certified reference materials and a continuing calibration blank. Reference materials NIST 2976 and ERM-CE464 were used to evaluate the calibration on the more sensitive and less sensitive cells, respectively. This approach has been incorporated by the United States Environmental Protection Agency (EPA) in EPA SW-846 Method 7473 for analyzing solid waste and leachate (USEPA 1998). Instrument detection limit was $0.05 \mathrm{ng} \mathrm{THg}$ and final results for $\mathrm{THg}$ concentration are reported in $\mu \mathrm{g} / \mathrm{g}$ wet weight (ww).

\section{Statistical approach}

Using an information-theoretic approach, we built two linear mixed model candidate sets to determine a statistically relevant spatial extent for land cover extraction, as well as which spatial and environmental parameters are associated with blood $\mathrm{THg}$ variation in tidal marsh sparrows among marsh sites. We selected independent variables based on a set of a priori hypotheses (Burnham and Anderson 2002) derived from known dynamics of $\mathrm{Hg}$ in the environment, and scaled these variables $(\mu=0, \mathrm{sd}=1)$ because raw values occurred at different orders of magnitude. We constructed models in R (v. 3.6.2; R Core Team 2019) using the package "'lmerTest"' (Kuznetsova et al. 2017), and fit models with maximum likelihood 
estimations (Zuur et al. 2009). Model selection was performed using second-order Akaike's Information Criterion for small-sample sizes ( $\mathrm{AIC}_{\mathrm{C}}$; Burnham and Anderson 2002).

We inspected the distribution of the blood THg concentrations for normality using quantile-quantile plots and a Shapiro-Wilk normality test, and rejected the null hypothesis that the data were normally distributed $(\mathrm{W}=0.881, \mathrm{p}<0.001)$. To achieve normality, we used a natural $\log$-transformation $(\mathrm{W}=0.979, \mathrm{p}=0.054)$. Four high outliers were present prior to transformation, but were included in the analysis because we had no reason to believe they were erroneous. Following transformation, there was no evidence that homogeneity of variance, normality of residuals, and normality of random effects assumptions were violated, based on visually inspecting quantile-quantile plots and plotted residuals versus predicted values (Zuur et al. 2009).

To populate the full linear model, we extracted $30 \times 30 \mathrm{~m}$ resolution land cover data (percent of total area) around each sampling point from the National Land Cover Database 2016 CONUS data (NLCD, Yang et al. 2018) and lumped land cover types into 3 relevant categories: wetland (NLCD categories 90 and 95 combined), forest (NLCD categories 41, 42, 43, and 52 combined), and developed land (NLCD categories 21, 22, 23, and 24 combined). We also included cumulative average annual precipitation data around each sampling point at a 30 -second resolution sourced from WorldClim Version 2.0 Bioclimatic variable "BIO12" using the R package "raster" (Hijmans 2018) to account for potential differences in deposition rates throughout the sampling range. We included species as a fixed effect because the uptake of $\mathrm{MeHg}$ occurs mainly through diet; and the interspecific foraging differences and relative size differences between species (Woolfenden 1968) could influence MeHg uptake as measured in 
the blood. To account for geographic variation in $\mathrm{Hg}$ deposition, prey availability, marsh hydrology, and other spatially variable conditions, we initially included latitude and longitude as fixed effects, and included marsh site as a random intercept in all models. When investigating appropriate spatial scales for the analysis (see below), we discovered that some of our variables were highly correlated at larger spatial scales, as indicated by variation inflation factors (VIF > 3) and correlation coefficients $\left(R^{2}>0.7\right)$ using R package "usdm" (Hair et al. 2010; Naimi et al. 2014). After removing latitude, longitude, and percent area of wetlands from the full model, there was no evidence of multicollinearity at any of the spatial scales we evaluated.

To test for correlations between tidal marsh sparrow THg concentrations and landscape characteristics surrounding sampling points, we attempted to define a statistically relevant spatial extent, or "scale of effect," for the independent variables. To accomplish this, we compared linear mixed models of identical structure, but with spatial attributes extracted within different buffer radii (Jackson and Fahrig 2012). Wiener and Shields (2000) demonstrated that industrially contaminated wetlands produced and exported $\mathrm{MeHg} 25 \mathrm{~km}$ downstream from the Sudbury River, Massachusetts, and Hildebrand et al. (1980) detected noticeable levels of THg in crayfish $130 \mathrm{~km}$ downstream from a chemical processing plant. Thus, we selected and compared buffer radii at $1-\mathrm{km}$ increments from $1-10 \mathrm{~km}$ and at $5-\mathrm{km}$ increments from $15-50 \mathrm{~km}$ to explore a range of potentially relevant scales. The model used to compare scales contained independent variables that would reasonably be influenced by radius selection: developed and forested land cover, in addition to cumulative average annual precipitation, within a 1-50 $\mathrm{km}$ radius around each sampling point. We defined the scale of effect to be the buffer radius that resulted in the lowest model $\mathrm{AIC}_{\mathrm{C}}$ value. 
To investigate which spatial and environmental parameters affect blood $\mathrm{THg}$ variation in tidal marsh sparrows, we constructed a set of 16 candidate models, which included a global model with all fixed effects, all possible reduced model combinations, as well as a null model with only site as a random effect. Fixed effects represented a priori hypotheses that tidal marsh sparrow blood THg concentrations are affected by the percentage of forested or developed land surrounding each sampling point, the species, and the cumulative average annual precipitation surrounding each point via its effect on atmospheric deposition. We averaged all models in the candidate set to obtain coefficient estimates for each independent variable using "MuMIn" (Bartón 2019). We then estimated 95\% confidence intervals and summed Akaike weights $\left(w_{i}\right)$ across all models containing each fixed effect to determine whether each independent variable affected THg levels. If a parameter had a 95\% CI that overlapped zero and a summed $w_{i}<0.75$, we concluded that our data provided little support for a relationship between the variable and blood THg in marsh sparrows (Smith et al. 2018).

\section{Results}

Throughout the sampling range, the mean blood THg concentration ( $\pm 1 \mathrm{SD}$ ) was $0.531 \pm 0.287$ $\mu \mathrm{g} / \mathrm{g}$ ww for saltmarsh sparrows $(\mathrm{n}=67)$ and $0.442 \pm 0.316 \mu \mathrm{g} / \mathrm{g}$ ww for seaside sparrows $(\mathrm{n}=$ 53). Individual THg concentrations ranged from $0.135-1.420 \mu \mathrm{g} / \mathrm{g} w \mathrm{w}$ for saltmarsh sparrows and $0.153-1.530 \mu \mathrm{g} / \mathrm{g}$ ww for seaside sparrows. We detected the lowest mean sparrow concentrations at Idlewild Park, New York $(0.187 \pm 0.068 \mu \mathrm{g} / \mathrm{g} w w)$ and the highest at Edwin B. Forsythe National Wildlife Refuge - Great Bay, New Jersey $(1.057 \pm 0.341 \mu \mathrm{g} / \mathrm{g}$ ww) (Table 1, Fig. 1). 
Models with buffer radii of $20-45 \mathrm{~km}$ were statistically indistinguishable $\left(\Delta \mathrm{AIC}_{\mathrm{C}}<2\right.$, Appendix 1), however, a 30-km buffer resulted in the lowest $\mathrm{AIC}_{\mathrm{C}}$ value, and was thus chosen as the most appropriate scale for describing the landscape. The top five models in our candidate set, accounting for $62 \%$ of total model weight, were statistically indistinguishable $\left(\Delta \mathrm{AIC}_{\mathrm{C}}<2\right.$, Table 2). Species was included as a fixed effect in all six top-performing models, and the model containing species and a random site effect had 5.4 times more weight than the model with the random site effect alone, suggesting interspecific differences in blood $\mathrm{THg}$ concentrations. Adding other independent variables did not result in better supported models (Table 2); which is consistent with the finding that, after conditional model averaging, all independent variables except for species had estimated $95 \%$ confidence intervals that included zero (Table 3 ).

Table 1 Location information, sample sizes (n), and species blood total mercury (THg) concentrations (mean $\pm \mathrm{SD}$ and range) for all sampling locations, Maine to Virginia, USA, June 1 to July 31,2018 . A dash (-) indicates that there are no data to report

\begin{tabular}{|c|c|c|c|c|c|c|}
\hline \multirow{2}{*}{$\begin{array}{c}\text { Location } \\
\text { (latitude, longitude) }\end{array}$} & \multicolumn{3}{|c|}{ Saltmarsh sparrow THg $(\mu \mathrm{g} / \mathrm{g}$ ww) } & \multicolumn{3}{|c|}{ Seaside sparrow THg $(\mu \mathrm{g} / \mathrm{g}$ ww) } \\
\hline & $\mathbf{n}$ & Mean \pm SD & Range & $\mathbf{n}$ & Mean \pm SD & Range \\
\hline $\begin{array}{l}\text { South Thomaston, Maine } \\
(44.077999,-69.142495)\end{array}$ & 6 & $0.51 \pm 0.14$ & $0.37-0.78$ & - & - & - \\
\hline $\begin{array}{l}\text { Scarborough Marsh WMA, } \\
\text { Maine } \\
(43.565488,-70.365070)\end{array}$ & 3 & $0.33 \pm 0.07$ & $0.27-0.40$ & - & - & - \\
\hline $\begin{array}{l}\text { Rachel Carson NWR - Eldridge } \\
\text { Rd., Maine } \\
(43.292158,-70.577234)\end{array}$ & 4 & $0.46 \pm 0.09$ & $0.34-0.53$ & - & - & - \\
\hline $\begin{array}{l}\text { Rachel Carson NWR - Furbish } \\
\text { Rd., Maine } \\
(43.280176,-70.584196)\end{array}$ & 4 & $0.45 \pm 0.18$ & $0.31-0.71$ & - & - & - \\
\hline $\begin{array}{l}\text { Barn Island WMA, Connecticut } \\
(41.337533,-71.866209)\end{array}$ & 4 & $0.64 \pm 0.03$ & $0.61-0.67$ & 1 & 0.52 & - \\
\hline $\begin{array}{l}\text { Quonochontaug, Rhode Island } \\
(41.333557,-71.716765)\end{array}$ & 4 & $0.36 \pm 0.05$ & $0.31-0.42$ & - & - & - \\
\hline $\begin{array}{l}\text { Idlewild Park, New York } \\
(40.653427,-73.752154)\end{array}$ & 1 & 0.13 & - & 2 & $0.21 \pm 0.07$ & $0.16-0.26$ \\
\hline
\end{tabular}


Gilgo State Park, New York (40.642785, -73.319184)

Marine Nature Study Area, New

York

(40.621389, -73.621598)

North Cinder Island, New York (40.611991, -73.610016)

North Cinder Island, New York (40.605962, -73.611136)

Conaskonk Point, New Jersey (40.455750, -74.176680)

Wrangle Creek, New Jersey $(39.837090,-74.150070)$

Edwin B. Forsythe NWR -

Manahawkin, New Jersey

(39.691680,-74.205150)

Edwin B. Forsythe NWR -

Great Bay, New Jersey

(39.527792, -74.444502)

Cohansey River WMA, New

Jersey

(39.366050, -75.358540)

New Sweden WMA, New

Jersey

(39.310620,-75.233730)

Slaughter Beach, Delaware

(38.895236, -75.290328)

Prime Hook NWR, Delaware

(38.815090, -75.229770)

Rehoboth Bay, Delaware

(38.693920, -75.138890)

Fishing Bay WMA - Elliot

Island Rd., Maryland

(38.351900, -75.936660)

Fishing Bay WMA - Great

Marsh Point, Maryland

(38.350410, -75.961750)

Fishing Bay WMA - Cedar

Creek Rd., Maryland

(38.318790, -76.052950)

Deal Island WMA, Maryland

(38.162700, -75.866040)

Johnson Bay - Taylor Landing,

Maryland

(38.078150, -75.363830)
4

$0.72 \pm 0.10$

$0.62-0.85$

$0.79 \pm 0.18$

$0.60-0.96$

3

1.06

-

$0.92 \pm 0.14$

$0.83-1.02$

0.95

-

$0.64 \pm 0.05 \quad 0.60-0.68$

$0.34 \pm 0.02$

$0.33-0.36$

$0.33 \pm 0.07 \quad 0.28-0.38$

$0.85 \pm 0.12$

$0.71-0.95$

$1.10 \pm 0.35$

0.78-1.48

$0.66 \pm 0.30$

0.48-1.01

0.53

3

$1.09 \pm 0.25$

$0.88-1.36$

3

$1.02 \pm 0.48$

$0.58-1.53$

$0.57 \pm 0.08$

0.49-0.65

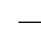

3

$0.94 \pm 0.42$

$0.67-1.42$

$0.57 \pm 0.04$

$0.53-0.60$

$0.49 \pm 0.07$

0.44-0.57

3

$0.34 \pm 0.05$

0.29-0.40

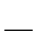

3

$0.24 \pm 0.05$

$0.19-0.28$

$0.23 \pm 0.08$

$0.17-0.31$

$0.26+0.02$

$0.24-0.28$

3

$0.21 \pm 0.02$

0.19-0.24

2

$0.17 \pm 0.03$

$0.15-0.20$

2

$0.27 \pm 0.08$

$0.21-0.33$

3

$0.29 \pm 0.05$

$0.25-0.35$

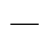

3

$0.22 \pm 0.01$

$0.21-0.23$

$0.19 \pm 0.05$

$0.16-0.25$ 


\begin{tabular}{|c|c|c|c|c|c|c|}
\hline $\begin{array}{l}\text { Johnson Bay - Sandy Point, } \\
\text { Maryland } \\
(38.069520,-75.369890)\end{array}$ & 2 & $0.23 \pm 0.03$ & $0.21-0.25$ & 3 & $0.17 \pm 0.01$ & $0.15-0.18$ \\
\hline $\begin{array}{l}\text { Chincoteague NWR, Virginia } \\
(37.973850,-75.327360)\end{array}$ & 1 & 0.38 & - & 3 & $0.33 \pm 0.09$ & $0.22-0.42$ \\
\hline
\end{tabular}

Table 2 Model-selection results examining the effects of spatial, environmental, and biological parameters on the natural log-transformed blood THg concentrations $(\mu \mathrm{g} / \mathrm{g} \mathrm{ww})$ of breeding tidal marsh sparrows in salt marshes from Maine to Virginia, USA, June 1 to July 31, 2018. Site is a random variable in all models as indicated by $(1 \mid$ Site $)$

\begin{tabular}{|c|c|c|c|c|c|}
\hline Model & $\mathbf{A I C}_{\mathbf{C}}$ & $\Delta \mathbf{A I C}_{\mathbf{C}}$ & $w_{i}$ & $-\log L$ & $\boldsymbol{K}$ \\
\hline Developed + Forest + Precipitation + Species $+(1 \mid$ Site $)$ & 83.594 & 0.000 & 0.224 & -34.297 & 7 \\
\hline Developed + Forest + Species $+(1 \mid$ Site $)$ & 85.042 & 1.447 & 0.109 & -36.149 & 6 \\
\hline Developed + Species $+(1 \mid$ Site $)$ & 85.071 & 1.477 & 0.107 & -37.273 & 5 \\
\hline Species $+(1 \mid$ Site $)$ & 85.387 & 1.792 & 0.092 & -38.519 & 4 \\
\hline Developed + Precipitation + Species $+(1 \mid$ Site $)$ & 85.563 & 1.968 & 0.084 & -36.409 & 6 \\
\hline Precipitation + Species $+(1 \mid$ Site $)$ & 85.619 & 2.0245 & 0.081 & -37.547 & 5 \\
\hline Developed + Forest + Precipitation $+(1 \mid$ Site $)$ & 85.666 & 2.072 & 0.079 & -36.462 & 6 \\
\hline Forest + Precipitation + Species $+(1 \mid$ Site $)$ & 86.237 & 2.642 & 0.059 & -36.747 & 6 \\
\hline Forest + Species $+(1 \mid$ Site $)$ & 87.009 & 3.415 & 0.041 & -38.242 & 5 \\
\hline Developed + Forest $+(1 \mid$ Site $)$ & 87.453 & 3.859 & 0.033 & -38.464 & 5 \\
\hline Developed + (1 | Site $)$ & 88.432 & 4.837 & 0.019 & -40.042 & 4 \\
\hline$(1 \mid$ Site $)$ & 88.804 & 5.209 & 0.017 & -41.298 & 3 \\
\hline Forest + Precipitation $+(1 \mid$ Site $)$ & 88.980 & 5.386 & 0.015 & -39.227 & 5 \\
\hline Developed + Precipitation $+(1 \mid$ Site $)$ & 88.985 & 5.389 & 0.015 & -39.229 & 5 \\
\hline Precipitation $+(1 \mid$ Site $)$ & 89.101 & 5.506 & 0.014 & -40.376 & 4 \\
\hline Forest $+(1 \mid$ Site $)$ & 89.976 & 6.381 & 0.009 & -40.814 & 4 \\
\hline
\end{tabular}


Table 3 Conditional model-averaged parameter estimates ( \pm adjusted SE), unconditional 95\% confidence intervals, summed Akaike weights $\left(w_{i}\right)$, p-values, VIF scores, as well as unscaled means $( \pm 1 \mathrm{SD})$ and ranges for each parameter included in the candidate set. There was no evidence of multicollinearity, as indicated by VIF values $<3$ from the full model

\begin{tabular}{|c|c|c|c|c|c|c|c|}
\hline Parameter & VIF & $\begin{array}{c}\text { Mean }( \pm 1 \\
\text { SD) }\end{array}$ & Range & $\begin{array}{c}\text { Estimate } \pm \\
\text { SE }\end{array}$ & $95 \% \mathrm{CI}$ & $w_{i}$ & $p$ \\
\hline $\begin{array}{c}\% \text { developed } \\
\text { land }\end{array}$ & 1.099 & $0.134 \pm 0.139$ & $0.024-0.479$ & $0.186 \pm 0.09$ & $\begin{array}{c}-0.003 \text { to } \\
0.374\end{array}$ & 0.67 & 0.054 \\
\hline$\%$ forest & 1.159 & $0.139 \pm 0.096$ & $0.031-0.319$ & $0.177 \pm 0.108$ & $\begin{array}{c}-0.035 \text { to } \\
0.389\end{array}$ & 0.57 & 0.101 \\
\hline $\begin{array}{l}\text { Precipitation } \\
\quad(\mathrm{mm})\end{array}$ & 1.057 & $\begin{array}{c}2772994 \pm \\
456396\end{array}$ & $\begin{array}{l}1820447- \\
3751937\end{array}$ & $\begin{array}{c}-0.163 \pm \\
0.097\end{array}$ & $\begin{array}{c}-0.353 \text { to } \\
0.026\end{array}$ & 0.57 & 0.092 \\
\hline Species* & - & - & - & $\begin{array}{c}-0.121 \pm \\
0.054\end{array}$ & $\begin{array}{l}-0.227 \text { to } \\
-0.015\end{array}$ & 0.80 & 0.026 \\
\hline
\end{tabular}

* Modeling estimate for seaside sparrow in reference to saltmarsh sparrow
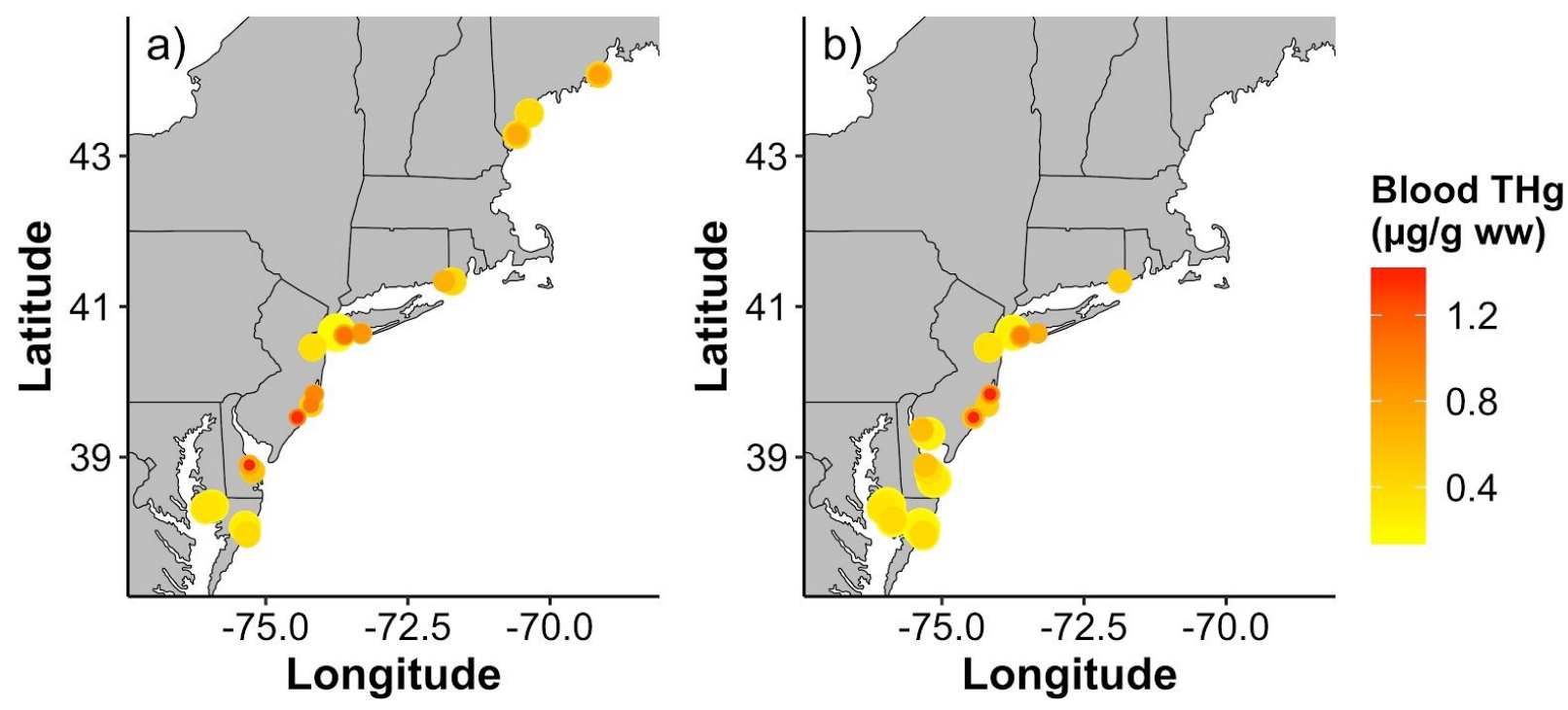

Fig. 1 Map of blood THg concentrations ( $\mu \mathrm{g} / \mathrm{g}$ ww) of breeding a) saltmarsh sparrows and b) seaside sparrows for all sampling locations from Maine to Virginia, USA, June 1 to July 31 , 2018 


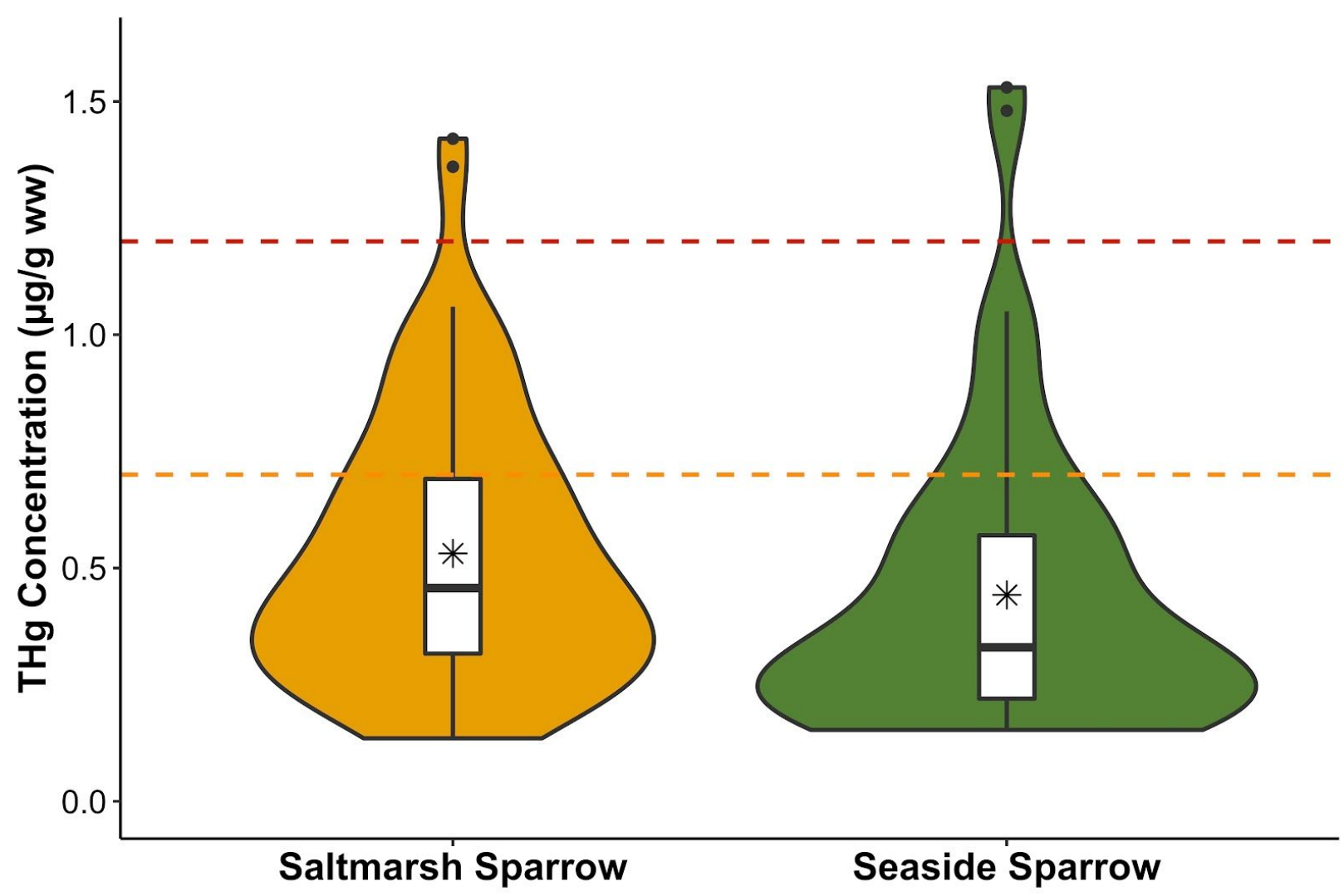

Fig. 2 Blood THg concentrations $(\mu \mathrm{g} / \mathrm{g} \mathrm{ww})$ of breeding tidal marsh sparrows from Maine to Virginia, USA, June 1 to July 31, 2018. The "violin" shapes represent the vertically-oriented distribution of $\mathrm{THg}$ concentrations per species. The boxplots display the outliers (dots), maximum and minimum concentration excluding the outliers (ends of whiskers), first and third quartile (central box), median (horizontal black line), and mean $(*)$ THg concentration per species. Dashed horizontal lines indicate the $0.7 \mu \mathrm{g} / \mathrm{g}$ ww 10\% effect concentration (EC10) and the $1.2 \mu \mathrm{g} / \mathrm{g}$ ww $20 \%$ effect concentration (EC20) defined by Jackson et al. (2011)

\section{Discussion}

Our conditional model-averaged results indicated that saltmarsh sparrows tended to have higher blood THg concentrations than seaside sparrows both when present at the same marsh sites and across their ranges (Table 1, Appendix 2). These results are congruent with previous studies documenting elevated saltmarsh sparrow blood $\mathrm{THg}$ concentrations relative to sympatric marsh sparrow species (Shriver et al. 2006; Ruskin et al. In prep.). However, these results differ 
from those of Warner et al. (2010), who found no differences between saltmarsh and seaside sparrows in coastal Delaware, though their sample of saltmarsh sparrows was relatively small. We hypothesize that interspecific differences in $\mathrm{THg}$ are due to differences in $\mathrm{MeHg}$ exposure through diet or differential foraging preferences. The trophic level at which an organism feeds is one of the principal mechanisms of bioaccumulation and magnification (Evers et al. 2005). Some dietary specialization exists between our focal species (Greenlaw et al. 2020), potentially leading to differences in the amount of MeHg-rich prey items taken. For instance, Post and Greenlaw (2006) documented that amphipods (order Amphipoda) and wolf spiders (family Lycosidae) were the first and fourth most important prey item for saltmarsh sparrows, respectively, but ranked much lower for seaside sparrows. Amphipods are scavengers that consume organic matter that originates from aquatic environments (Moore and Francis 1985; Persson 1999) and have elevated levels of $\mathrm{Hg}$ relative to organisms occupying higher trophic levels (George and Batzer 2008). In addition, due to their predatory nature and elevated capacity for $\mathrm{MeHg}$ biomagnification, spiders pose a potential risk to arachnivorous songbirds (Cristol et al. 2008; Gann et al. 2015). Shriver et al. (2006) found a similar pattern between Nelson's and Saltmarsh sparrows breeding in coastal Maine salt marshes and attributed differences in $\mathrm{Hg}$ to variation in foraging strategies between the taxa. Quantifying MeHg concentrations within food items consumed by tidal marsh sparrows remains an unexplored, yet crucial step in characterizing MeHg exposure for these species, as well as $\mathrm{Hg}$ dynamics and biomagnification within saltmarsh estuarine food webs as a whole.

Defining relevant land cover characteristics at an appropriate spatial scale is challenging. Hg can be transported over large distances via atmospheric and aquatic systems, and coastal 
wetlands can have differential $\mathrm{Hg}$ loading and site-specific biogeochemical processes — all of which can influence MeHg exposure of wildlife. Relevant spatial boundaries likely vary in both size and shape across marshes, depending on marsh characteristics. Despite exploring the effects of geographic scale on model fit, we found no evidence that the proportions of developed or forested land cover were associated with blood THg concentrations of tidal marsh sparrows. Similarly, we found no evidence that cumulative average annual precipitation was associated. These landscape-level factors were intended to serve as a proxy for the amount of regional atmospheric deposition and the potential abundance of $\mathrm{Hg}$ point sources, such as industrial facilities and landfills, surrounding sampling points. While such parameters were not directly accounted for in our model set, they may play an important role in influencing $\mathrm{MeHg}$ exposure of tidal marsh sparrows.

Several water quality parameters that correlate with increased organismal $\mathrm{Hg}$ bioaccumulation and MeHg production in wetlands were also unaccounted for in this study, including low pH and high dissolved organic carbon (DOC) levels (Wiener et al. 1990; Wren 1991; Scheuhammer and Graham 1999; Ravichandran 2004; Hall et al. 2008). High salinity sediments may promote $\mathrm{Hg}$ demethylation (Compeau and Bartha 1987) and the frequency of inundations of each marsh could influence methylation rates and $\mathrm{MeHg}$ mobilization from anaerobic wetland sediments (Snodgrass et al. 2000). Freshwater wetlands that are shallow and experience long bouts of periodic drying have higher $\mathrm{THg}$ and $\mathrm{MeHg}$ concentrations in water, sediment, and fish than those with consistently moist sediments (Caldwell and Canavan 1998; Snodgrass et al. 2000). While poorly studied in saline environments, brackish water marshes that experience longer periods between inundations (ie. a shorter hydroperiod) have more time to 
dessicate, thus elevating MeHg export and bioavailability (Hall et al. 2008). Future studies seeking to characterize MeHg bioaccumulation in coastal estuaries should obtain a comprehensive understanding of the unique biogeochemical and hydrological dynamics of each marsh site whenever possible.

Previous research suggests that up to $62 \%$ of saltmarsh sparrows breeding from Maine to New York, as well as $>75 \%$ of saltmarsh sparrows and $>60 \%$ of seaside sparrows wintering in North Carolina, are potentially at risk of deleterious MeHg effects on reproduction (Winder 2012; Lane et al. 2020). A severe limitation in producing precise at-risk population estimates is the lack of toxicity reference values for our focal species. A common practice in ecotoxicological wildlife monitoring is to extrapolate toxicity reference values across species because many species have not been studied (Warner et al. 2010; Lane et al. 2011, 2020; Winder 2012). Researchers are often cautioned against this practice because the potential exists for extrapolation to be severely biased (USEPA 2007). Therefore, we provide comparative context with caution as we lack any direct evidence of how THg may influence sparrow reproduction. Based on a predictive linear model using blood THg concentrations from Carolina wrens, a non-migratory passerine breeding along two contaminated rivers in Virginia, USA, Jackson et al. (2011) proposed that female Carolina wrens with blood THg concentrations of $0.7-1.2 \mu \mathrm{g} / \mathrm{g}$ ww and $1.2-1.7 \mu \mathrm{g} / \mathrm{g}$ ww were likely at risk of a $10-20 \%$ and $20-30 \%$ reduction in nesting success, respectively (but see Fuchsman et al. 2017). Using the Jackson et al. (2011) potential risk categories, we estimated that approximately $22 \%$ of saltmarsh and $11 \%$ of seaside sparrows sampled from Maine to Virginia may be at risk of a $10-20 \%$ reduction in nesting success, while 
$3 \%$ of saltmarsh and $4 \%$ of seaside sparrows may be at risk of a $20-30 \%$ reduction in nesting success.

Although approximately $21 \%$ of the sampled birds had blood THg levels above the proposed $10 \%$ effect concentration (EC10), $58 \%$ of saltmarsh sparrows and $33 \%$ of seaside sparrows sampled in coastal New Jersey were above the EC10. Coastal New Jersey is estimated to support $37 \%$ of the global saltmarsh sparrow breeding population, and $22 \%$ of the seaside sparrows that breed in the northeastern USA (Wiest et al. 2016). Elevated MeHg exposure cases have also been documented previously in the Northeast (Lane et al. 2011, 2020; Kopec et al. 2018).

Sea-level rise is the principal driver of tidal marsh sparrow population declines (Shriver et al. 2007; Gjerdrum et al. 2008), and could cause the extinction of the saltmarsh sparrow by mid-century (Correll et al. 2017; Field et al. 2017, 2018; Roberts et al. 2019). Concurrently, some tidal marsh sparrows may face challenges coming from industrial practices in terrestrial systems that expose them and other wildlife to potentially dangerous levels of $\mathrm{Hg}$ contamination. For tidal marsh sparrows to persist into the next century, significant conservation efforts are required (Hartley and Weldon 2020). Ensuring that secondary factors such as heavy metal contamination do not compromise the persistence of remaining populations is beneficial to ensuring long-term success - as long as mitigating the effects of sea-level rise on tidal flooding remains the primary conservation priority. 


\section{References}

Ackerman JT, Herzog MP, Schwarzbach SE (2013) Methylmercury is the predominant form of mercury in bird eggs: a synthesis. Environ Sci Technol 47(4):2052-2060. https://doi.org/10.1021/es304385y

Bartoń K (2020) MuMIn: multi-model inference. R package version 1.43.17. https://CRAN.R-project.org/package=MuMIn

Bayard TS, Elphick CS (2011) Planning for sea-level rise: quantifying patterns of saltmarsh sparrow (Ammodramus caudacutus) nest flooding under current sea-level conditions. Auk 128(2):393-403. https://doi.org/10.1525/auk.2011.10178

BirdLife International (2018) Ammospiza caudacuta. The IUCN Red List of Threatened Species. https://dx.doi.org/10.2305/IUCN.UK.2018-2.RLTS.T22721129A131887480.en

Bouton SN, Frederick PC, Spalding MG, McGill H (1999) Effects of chronic, low concentrations of dietary methylmercury on the behavior of juvenile great egrets. Environ Toxicol Chem 18(9):1934-1939. https://doi.org/10.1002/etc.5620180911

Brasso RL, Abdel Latif MK, Cristol DA (2010) Relationship between laying sequence and mercury concentration in tree swallow eggs. Environ Toxicol Chem 29(5):1155-1159. https://doi.org/10.1002/etc.144

Burnham KP, Anderson DR (2002) Model selection and multimodel inference: a practical information-theoretic approach, 2nd edn. Springer, New York. https://doi.org/10.1007/b97636 
Caldwell CA, Canavan M (1998) Spatial and temporal distribution of mercury in Caballo and Elephant Butte Reservoirs, Sierra County, New Mexico. WRRI Tech. Completion Rep. 306, New Mexico Water Resources Research Institute, Las Cruces, NM

Compeau GC, Bartha R (1985) Sulfate-reducing bacteria: principal methylators of mercury in anoxic estuarine sediment. Appl Environ Microbiol 50(2): 498-502

Compeau GC, Bartha R (1987) Effect of salinity on mercury-methylating activity of sulphate-reducing bacteria in estuarine sediments. Appl Environ Microbiol 53(2):261-265

Correll MD, Wiest WA, Hodgman TP, Shriver WG, Elphick CS, McGill BJ, O’Brien KM, Olsen BJ (2017) Predictors of specialist avifaunal decline in coastal marshes. Conserv Biol 31(1):172-182. https://doi.org/10.1111/cobi.12797

Cristol DA, Brasso RL, Condon AM, Fovargue RE, Friedman SL, Hallinger KK, Monroe AP, White AE (2008) The movement of aquatic mercury through terrestrial food webs. Science 320(5874):335. https://doi.org/10.1126/science.1154082

Driscoll CT, Blette V, Yan C, Schofield CL, Munson R, Holsapple J (1995) The role of dissolved organic carbon in the chemistry and bioavailability of mercury in remote Adirondack lakes. Water Air Soil Pollut 80:499-508

Driscoll CT, Holsapple J, Schofield CL, Munson R (1998) The chemistry and transport of mercury in a small wetland in the Adirondack region of New York, USA.

Biogeochemistry 40:137-146 
Evers DC (2018) The effects of methylmercury on wildlife: a comprehensive review and approach for interpretation. In: Dellasala DA, Goldstein MI (eds) Encyclopedia of the anthropocene, vol. 5. Elsevier, New York, pp 181-194

Evers DC, Burgess NM, Champoux L, Hoskins B, Major A, Goodale WM, Taylor RJ, Poppenga R, Daigle T (2005) Patterns and interpretation of mercury exposure in freshwater avian communities in northeastern North America. Ecotoxicology 14:193-221

Evers DC, Savoy L, DeSorbo CR, Yates D, Hanson W, Taylor KM, Siegel L, Cooley JH, Bank M, Major A, Munney K, Vogel HS, Schoch N, Pokras M, Goodale W, Fair J (2008) Adverse effects from environmental mercury on breeding common loons. Ecotoxicology 17:69-81

Field CR, Bayard TS, Gjerdrum C, Hill JM, Meiman S, Elphick CS (2017) High-resolution tide projections reveal extinction threshold in response to sea-level rise. Global Change Biol 23(5):2058-2070. https://doi.org/10.1111/gcb.13519

Field CR, Ruskin KJ, Benvenuti B, Borowske A, Cohen JB, Garey L, Hodgman TP, Kern RA, King E, Kocek AR, Kovach AI, O’Brien KM, Olsen BJ, Pau N, Roberts SG, Shelly E, Shriver WG, Walsh J, Elphick CS (2018) Quantifying the importance of geographic replication and representativeness when estimating demographic rates, using a coastal species as a case study. Ecography 41:971-981. https://doi.org/10.1111/ecog.02424.

Fuchsman PC, Brown LE, Henning MH, et al (2017) Toxicity reference values for methylmercury effects on avian reproduction: critical review and analysis. Environ Toxicol Chem 36:294-319. https://doi.org/10.1002/etc.3606 
Gann GL, Powell CH, Chumchal MM, Drenner RW (2015) Hg-contaminated terrestrial spiders pose a potential risk to songbirds at Caddo Lake (Texas/Louisiana, USA). Environ Toxicol Chem 34(2):303-306. https://doi.org/10.1002/etc.2796

George BM, Batzer D (2008) Spatial and temporal variations of mercury levels in Okefenokee invertebrates: Southeast Georgia. Environ Pollut 152(2):484-490. https://doi.org/10.1016/j.envpol.2007.04.030

Gilmour CC, Bloom NS (1995) A case study of mercury and methylmercury dynamics in a Hg-contaminated municipal wastewater treatment plant. Water Air Soil Pollut 80:799-803

Gjerdrum C, Sullivan-Wiley K, King E, Rubega MA, Elphick CS (2008) Egg and chick fates during tidal flooding of saltmarsh sharp-tailed sparrow nests. Condor 110(3):579-584. https://doi.org/10.1525/cond.2008.8559

Greenlaw JS, Elphick CS, Post W, Rising JD (2020) Saltmarsh Sparrow (Ammospiza caudacuta), version 1.0. In Rodewald PG (ed) Birds of the World. Cornell Lab of Ornithology, Ithaca. https://doi.org/10.2173/bow.sstspa.01

Hair Jr JF, Black WC, Babin BJ, Anderson RE (2010) Multivariate Data Analysis, 7th edn. Prentice Hall, Upper Saddle River

Hall BD, Aiken GR, Krabbenhoft DP, Marvin-DiPasquale M, Swarzenski CM (2008) Wetlands as principal zones of methylmercury production in southern Louisiana and the Gulf of $\begin{array}{lllll}\text { Mexico } & \text { region. } & \text { Environ } & \text { Pollut }\end{array}$ https://doi.org/10.1016/j.envpol.2007.12.017 
Hartley MJ, Weldon AJ (2020) Saltmarsh Sparrow Conservation Plan. Atlantic Coast Joint Venture, pp 122

Hijmans RJ (2020) raster: geographic data analysis and modeling. R package version 3.3-13. https://CRAN.R-project.org/package=raster

Hildebrand SG, Strand RH, Huckabee JW (1980) Mercury accumulation in fish and invertebrates of the North Fork Holston River, Virginia and Tennessee. J Environ Qual 9(3):393-400. https://doi.org/10.2134/jeq1980.00472425000900030013x

Hudson RJM, Gherini SA, Fitzgerald WF, Porcella DB (1995) Anthropogenic influences on the global mercury cycle: a model-based analysis. Water Air Soil Pollut 80:265-272. https://doi.org/10.1007/BF01189676

Jackson AK, Evers DC, Etterson MA, Condon AM, Folsom SB, Detweiler J, Schmerfeld J, Cristol DA (2011) Mercury exposure affects the reproductive success of a free-living terrestrial songbird, the Carolina wren (Thryothorus ludovicianus). Auk 128(4):759-769. https://doi.org/10.1525/auk.2011.11106

Jackson HB, Fahrig L (2012) What size is a biologically relevant landscape? Landsc Ecol 27(7):929-941. https://doi.org/10.1007/s10980-012-9757-9

Kopec DA, Bodaly RA, Lane OP, Evers DC, Leppold AJ, Mittelhauser GH (2018) Elevated mercury in blood and feathers of breeding marsh birds along the contaminated lower Penobscot River, Maine, USA. Science Tot Environ 634:1563-1579. https://doi.org/10.1016/j.scitotenv.2018.03.223 
Krabbenhoft DP, Benoit JM, Babiarz CL, Hurley JP, Andren AW (1995) Mercury cycling in the Allequash Creek watershed, northern Wisconsin. Water Air Soil Pollut 80:425-433. https://doi.org/10.1007/BF01189692

Kuznetsova A, Brockhoff PB, Christensen RHB (2017) lmerTest package: tests in linear mixed effects models. J Stat Softw 82(13):1-26. https://doi.org/10.18637/jss.v082.i13

Lane O, Adams EM, Pau N., O’Brien KM, Regan K, Farina M, Schneider-Moran T, Zarudsky J (2020) Long-term monitoring of mercury in adult saltmarsh sparrows breeding in Maine, Massachusetts and New York, USA 2000-2017. Ecotoxicology 29:1148-1160. https://doi.org/10.1007/s10646-020-02180-w

Lane OP, O’Brien KM, Evers DC, Hodgman TP, Major A, Pau N, Ducey MJ, Taylor R, Perry D (2011) Mercury in breeding saltmarsh sparrows (Ammodramus caudacutus caudacutus). Ecotoxicology 20:1984-1991. https://doi.org/10.1007/s10646-011-0740-z

Moore PG, Francis CH (1985) Some observations on food and feeding of the supralittoral beachhopper Orchestia gammarellus (Pallas) (Crustacea: Amphipoda). Ophelia 24(3):183-197. https://doi.org/10.1080/00785326.1985.10429727

Naimi B, Hamm NAS, Groen TA, Skidmore AK, Toxopeus AG (2014) Where is positional uncertainty a problem for species distribution modelling? Ecography 37:191-203. https://doi.org/10.1111/j.1600-0587.2013.00205.x

Niebla EE, Korte NE, Alesh BA, Fuller WH (1976) Effect of municipal landfill leachate on mercury movement through soils. Water Air Soil Pollut 5:399-401. https://doi.org/10.1007/BF00280840 
Ou L, Varian-Ramos CW, Cristol DA (2015) Effect of laying sequence on egg mercury in captive zebra finches: an interpretation considering individual variation. Environ Toxicol Chem 34(8):1787-1792. https://doi.org/10.1002/etc.2976

Persson, Lars-Eric (1999) Growth and reproduction in two brackish water populations of Orchestia gammarellus (Amphipoda: Talitridae) in the Baltic Sea. J Crustac Biol 19(1):53-59. https://doi.org/10.1163/193724099X00240

Post W, Greenlaw JS (2006) Nestling diets of coexisting salt marsh sparrows: opportunism in a $\begin{array}{llll}\text { food-rich } & \text { Environment. } & \text { Coasts }\end{array}$ https://doi.org/10.1007/BF02786527

Post W, Greenlaw JS (2020) Seaside Sparrow (Ammospiza maritima), version 1.0. In Rodewald PG (ed) Birds of the World. Cornell Lab of Ornithology, Ithaca. https://doi.org/10.2173/bow.seaspa.01

Ravichandran M (2004) Interactions between mercury and dissolved organic matter-a review. Chemosphere 55(3):319-331. https://doi.org/10.1016/j.chemosphere.2003.11.011

R Core Team (2019). R: a language and environment for statistical computing. R Foundation for Statistical Computing, Vienna. https://www.R-project.org/

Rea AW, Keeler GJ, Scherbatskoy T (1996) The deposition of mercury in throughfall and litterfall in the Lake Champlain watershed: a short-term study. Atmos Environ 30(19):3257-3263. https://doi.org/10.1016/1352-2310(96)00087-8

Rimmer CC, McFarland KP, Evers DC, Miller EK, Aubry Y, Busby D, Taylor RJ (2005) Mercury concentrations in Bicknell's thrush and other insectivorous passerines in 
montane forests of northeastern North America. Ecotoxicology 14:223-240. https://doi.org/10.1007/s10646-004-6270-1

Roberts SG, Longenecker RA, Etterson MA, Elphick CS, Olsen BJ, Shriver WG (2019) Preventing local extinctions of tidal marsh endemic seaside sparrows and saltmarsh sparrows in eastern North America. Condor 121(2):1-14. https://doi.org/10.1093/condor/duy024

Rosenberg KV, Kennedy JA, Dettmers R, et al (2016) Partners in Flight landbird conservation plan: 2016 revision for Canada and continental United States. Partners in Flight Science Committee, pp 1-119

Rule KL, Comber SDW, Ross D, Thornton A, Makropoulos CK, Rautiu R (2006) Diffuse sources of heavy metals entering an urban wastewater catchment. Chemosphere 63(1):64-72. https://doi.org/10.1016/j.chemosphere.2005.07.052

Ruskin KJ, Herring G, Borowske A, et al (In prep.) Mercury exposure of tidal marsh songbirds in the northeastern United States and its effects on nest survival

Scheuhammer AM (1987) The chronic toxicity of aluminium, cadmium, mercury, and lead in $\begin{array}{lllll}\text { birds: } & \text { a } & \text { review. } & \text { Environ }\end{array}$ https://doi.org/10.1016/0269-7491(87)90173-4

Scheuhammer AM, Graham JE (1999) The bioaccumulation of mercury in aquatic organisms from two similar lakes with differing $\mathrm{pH}$. Ecotoxicology 8:49-56. https://doi.org/10.1023/A:1008936910823 
Schwarzbach SE, Albertson JD, Thomas CM (2006) Effects of predation, flooding, and contamination on reproductive success of California clapper rails (Rallus longirostris obsoletus) in San Francisco Bay. Auk 123(1):45-60. https://doi.org/10.1093/auk/123.1.45

Shriver WG, Evers DC, Hodgman TP, MacCullough BJ, Taylor RJ (2006) Mercury in sharp-tailed sparrows breeding in coastal wetlands. Environ Bioindic 1(2):129-135. https://doi.org/10.1080/15555270600695734

Shriver WG, Vickery PD, Hodgman TP, Gibbs JP (2007) Flood tides affect breeding ecology of two sympatric sharp-tailed sparrows. Auk 124(2):552-560. https://oi.org/10.1093/auk/124.2.552

Smith MG, Kaiser SA, Sillett TS, Webster MS (2018) Variation in nest characteristics and brooding patterns of female black-throated blue warblers is associated with thermal cues. Auk 135(3):733-747. https://doi.org/10.1642/AUK-17-195.1

Snodgrass JW, Jagoe CH, Bryan AL Jr, Brant HA, Burger J (2000) Effects of trophic status and wetland morphology, hydroperiod, and water chemistry on mercury concentrations in fish. Can J Fish Aquat Sci 57(1):171-180. https://doi.org/10.1139/f99-199

St. Louis VL, Rudd JWM, Kelly CA, Beaty KG, Bloom NS, Flett RJ (1994) Importance of wetlands as sources of methyl mercury to boreal forest ecosystems. Can J Fish Aquat Sci 51(5):1065-1076. https://doi.org/10.1139/f94-106

US EPA (US Environmental Protection Agency) (1998) Method 7473 (SW-846): mercury in solids and solutions by thermal decomposition, amalgamation, and atomic absorption spectrophotometry, revision 0 . Washington, DC 
US EPA (US Environmental Protection Agency) (2007) Framework for metals risk assessment. EPA 120/R-07/001. Office of the Science Advisor Risk Assessment Forum, Washington, $\mathrm{DC}$

UNEP (United Nations Environment Programme) (2019) Global mercury assessment 2018. UN Environment Programme, Chemicals and Health Branch, Geneva

Warner SE, Shriver GW, Pepper MA, Taylor RJ (2010) Mercury concentrations in tidal marsh sparrows and their use as bioindicators in Delaware Bay, USA. Environ Monit Assess 171:671-679. https://doi.org/10.1007/s10661-010-1312-z

Wiener JG, Fitzgerald WF, Watras CJ, Rada RG (1990) Partitioning and bioavailability of mercury in an experimentally acidified Wisconsin lake. Environ Toxicol Chem 9(7):909-918

Wiener JG, Shields PJ (2000) Mercury in the Sudbury River (Massachusetts, U.S.A.): pollution history and synthesis of recent research. Can J Fish Aquat Sci 57(5):1053-1061. https://doi.org/10.1139/f00-039

Wiest WA, Correll MD, Olsen BJ, Elphick CS, Hodgman TP, Curson DR, Shriver WG (2016) Population estimates for tidal marsh birds of high conservation concern in the northeastern USA from a design-based survey. Condor 118(2):274-288. https://doi.org/10.1650/CONDOR-15-30.1

Winder VL (2012) Characterization of mercury and its risk in Nelson's, saltmarsh, and seaside sparrows. PLoS ONE 7(9):e44446. https://doi.org/10.1371/journal.pone.0044446 
Woolfenden GE (1968) Ammospiza maritima maritima (Wilson) northern seaside sparrow. In: Austin OL (ed) Life histories of North American cardinals, buntings, towhees, finches, sparrows, and their allies, parts 1-3. US National Museum Bulletin 237:819-831

Wren CD, Scheider WA, Wales DL, Muncaster BW, Gray IM (1991) Relation between mercury concentrations in walleye (Stizostedion vitreum vitreum) and northern pike (Esox lucius) in Ontario lakes and influence of environmental factors. Can J Fish Aquat Sci 48(1):132-139. https://doi.org/10.1139/f91-018

Yang L, Jin S, Danielson P, Homer C, Gass L, Bender SM, Case A, Costello C, Dewitz J, Fry J, Funk M, Granneman B, Liknes GC, Rigge M, Xian G (2018) A new generation of the United States National Land Cover Database: requirements, research priorities, design, and implementation strategies. ISPRS J Photogramm. Remote Sens 146:108-123. https://doi.org/10.1016/j.isprsjprs.2018.09.006

Zuur A, Ieno EN, Walker N, Saveliev AA, Smith GM (2009) Mixed effects models and extensions in ecology with R. Springer, New York. https://doi.org/10.1007/978-0-387-87458-6 
Appendix $1 \Delta \mathrm{AIC}_{\mathrm{C}}$ values for models with buffer radii from $1-50 \mathrm{~km}$. Graph indicates that 30 $\mathrm{km}$ is the best scale of effect for which developed and forested land cover, as well as cumulative average annual precipitation, surrounding each focal marsh can best predict the natural log-transformed blood $\mathrm{THg}$ concentrations $(\mu \mathrm{g} / \mathrm{g}$ ww) of breeding tidal marsh sparrows in salt marshes from Maine to Virginia, USA, June 1 to July 31, 2018

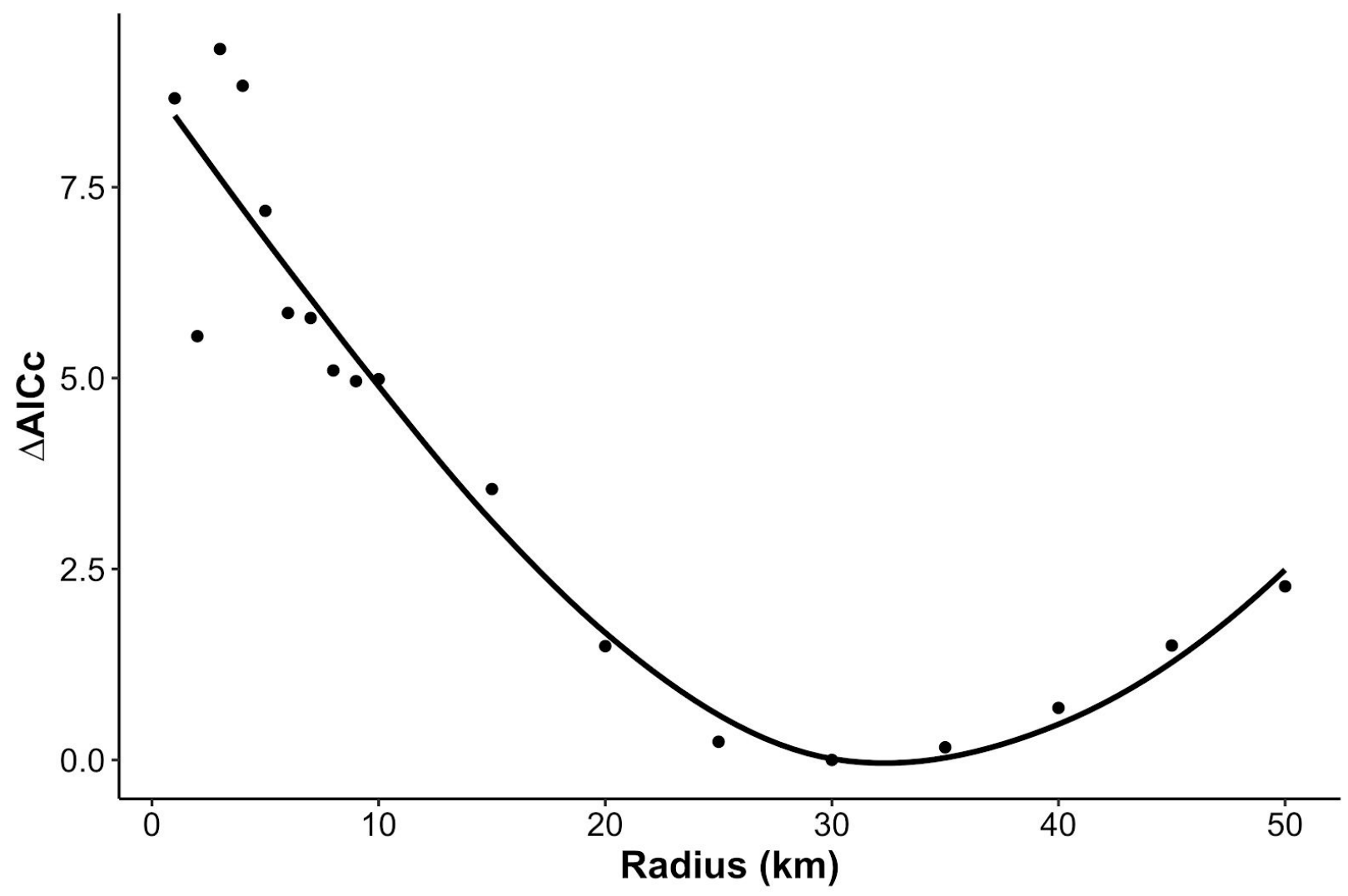

Appendix 2 Regional- and site-level tidal marsh sparrow blood THg concentration comparisons of other published works through time

\begin{tabular}{|c|c|c|c|c|c|c|c|c|c|}
\hline \multirow[t]{2}{*}{ Study Cited } & \multirow[t]{2}{*}{ Area } & \multirow[t]{2}{*}{$\begin{array}{l}\text { Marsh } \\
\text { Site }\end{array}$} & \multirow[t]{2}{*}{$\begin{array}{c}\text { Year } \\
\text { Sampled }\end{array}$} & \multicolumn{3}{|c|}{$\begin{array}{c}\text { Saltmarsh Sparrow THg }(\mu \mathrm{g} / \mathrm{g} \\
\text { ww) }\end{array}$} & \multicolumn{3}{|c|}{ Seaside Sparrow THg $(\mu \mathrm{g} / \mathrm{g}$ ww) } \\
\hline & & & & $\mathbf{n}$ & $\begin{array}{c}\text { Mean } \\
\text { SD }\end{array}$ & Range & $\mathbf{n}$ & $\begin{array}{l}\text { Mean } \\
\text { SD }\end{array}$ & Range \\
\hline This paper & $\begin{array}{c}\mathrm{ME}- \\
\mathrm{VA}\end{array}$ & - & 2018 & 67 & $\begin{array}{c}0.53 \pm \\
0.29\end{array}$ & $\begin{array}{c}0.13-1.4 \\
2\end{array}$ & 53 & $\begin{array}{c}0.44 \pm \\
0.32\end{array}$ & $0.15-1.5$ \\
\hline This paper & $\begin{array}{l}\mathrm{ME}- \\
\mathrm{NY}\end{array}$ & - & 2018 & 35 & $\begin{array}{c}0.54 \pm \\
0.22\end{array}$ & $\begin{array}{c}0.13-1.0 \\
6\end{array}$ & - & - & - \\
\hline Lane et al. 2011 & $\begin{array}{l}\mathrm{ME}- \\
\mathrm{NY}\end{array}$ & - & 2004-08 & 653 & - & $\begin{array}{c}0.14-3.7 \\
0\end{array}$ & - & - & - \\
\hline This paper & ME & - & 2018 & 17 & $\begin{array}{c}0.45 \pm \\
0.14\end{array}$ & $\begin{array}{c}0.27-0.7 \\
8\end{array}$ & - & - & - \\
\hline
\end{tabular}




\begin{tabular}{|c|c|c|c|c|c|c|c|c|c|}
\hline Lane et al. (2011) & ME & - & 2004-08 & 239 & - & $\begin{array}{c}0.22-1.4 \\
4\end{array}$ & - & - & - \\
\hline Shriver et al. (2006) & ME & - & 2001 & 53 & $\begin{array}{c}0.69 \pm \\
0.20\end{array}$ & $\begin{array}{c}0.34-1.2 \\
6\end{array}$ & - & - & - \\
\hline This paper & $\begin{array}{c}\text { DE Bay } \\
\text { (DE } \\
\text { side) }\end{array}$ & - & 2018 & 6 & $\begin{array}{c}0.72 \pm \\
0.36\end{array}$ & $\begin{array}{c}0.44-1.4 \\
2\end{array}$ & 6 & $\begin{array}{c}0.45 \pm \\
0.13\end{array}$ & $\begin{array}{c}0.29-0.6 \\
0\end{array}$ \\
\hline Warner et al. (2010) & $\begin{array}{c}\text { DE Bay } \\
\text { (DE } \\
\text { side) }\end{array}$ & - & $2006-07$ & 35 & - & $\begin{array}{c}0.19-0.8 \\
3\end{array}$ & 100 & - & $\begin{array}{c}0.15-2.1 \\
2\end{array}$ \\
\hline This paper & $\mathrm{ME}$ & $\begin{array}{c}\text { Scarborou } \\
\text { gh Marsh } \\
\text { WMA }\end{array}$ & 2018 & 3 & $\begin{array}{c}0.33 \pm \\
0.07\end{array}$ & $\begin{array}{c}0.27-0.4 \\
0\end{array}$ & - & - & - \\
\hline Lane et al. (2011) & ME & $\begin{array}{c}\text { Scarborou } \\
\text { gh Marsh } \\
\text { WMA }\end{array}$ & 2007 & 14 & $\begin{array}{c}0.52 \pm \\
0.24\end{array}$ & $\begin{array}{c}0.22-1.1 \\
0\end{array}$ & - & - & - \\
\hline Lane et al. (2011) & ME & $\begin{array}{c}\text { Scarborou } \\
\text { gh Marsh } \\
\text { WMA }\end{array}$ & 2004 & 15 & $\begin{array}{c}0.47 \pm \\
0.16\end{array}$ & $\begin{array}{c}0.23-0.8 \\
2\end{array}$ & - & - & 一 \\
\hline Lane et al. (2020) & ME & $\begin{array}{c}\text { Scarborou } \\
\text { gh Marsh } \\
\text { WMA }\end{array}$ & $2000-09$ & 62 & $\begin{array}{c}0.562 \pm \\
0.18\end{array}$ & - & - & - & - \\
\hline This paper & $\mathrm{ME}$ & $\begin{array}{l}\text { Rachel } \\
\text { Carson } \\
\text { NWR }\end{array}$ & 2018 & 8 & $\begin{array}{c}0.45 \pm \\
0.13\end{array}$ & $\begin{array}{c}0.31-0.7 \\
1\end{array}$ & - & - & - \\
\hline Lane et al. (2020) & ME & $\begin{array}{l}\text { Rachel } \\
\text { Carson } \\
\text { NWR }\end{array}$ & $2004-15$ & 121 & $\begin{array}{c}0.642 \pm \\
0.16\end{array}$ & - & - & - & 一 \\
\hline This paper & ME & $\begin{array}{l}\text { Rachel } \\
\text { Carson } \\
\text { NWR - } \\
\text { Furbish } \\
\text { Rd. }\end{array}$ & 2018 & 4 & $\begin{array}{c}0.45 \pm \\
0.18\end{array}$ & $\begin{array}{c}0.31-0.7 \\
1\end{array}$ & - & - & - \\
\hline Lane et al. (2011) & $\mathrm{ME}$ & $\begin{array}{l}\text { Rachel } \\
\text { Carson } \\
\text { NWR - } \\
\text { Furbish } \\
\text { Rd. }\end{array}$ & 2008 & 57 & $\begin{array}{c}0.70 \pm \\
0.19\end{array}$ & $\begin{array}{c}0.39-1.4 \\
0\end{array}$ & - & - & - \\
\hline Lane et al. (2011) & ME & $\begin{array}{l}\text { Rachel } \\
\text { Carson } \\
\text { NWR - } \\
\text { Furbish } \\
\text { Rd. }\end{array}$ & 2007 & 45 & $\begin{array}{c}0.71 \pm \\
0.12\end{array}$ & $\begin{array}{c}0.53-1.0 \\
0\end{array}$ & - & - & - \\
\hline Lane et al. (2011) & ME & $\begin{array}{l}\text { Rachel } \\
\text { Carson } \\
\text { NWR - } \\
\text { Furbish } \\
\text { Rd. }\end{array}$ & 2006 & 16 & $\begin{array}{c}0.73 \pm \\
0.11\end{array}$ & $\begin{array}{c}0.58-0.9 \\
5\end{array}$ & - & - & - \\
\hline Lane et al. (2011) & $\mathrm{ME}$ & Rachel & 2005 & 21 & $0.76 \pm$ & $0.47-1.4$ & - & - & - \\
\hline
\end{tabular}




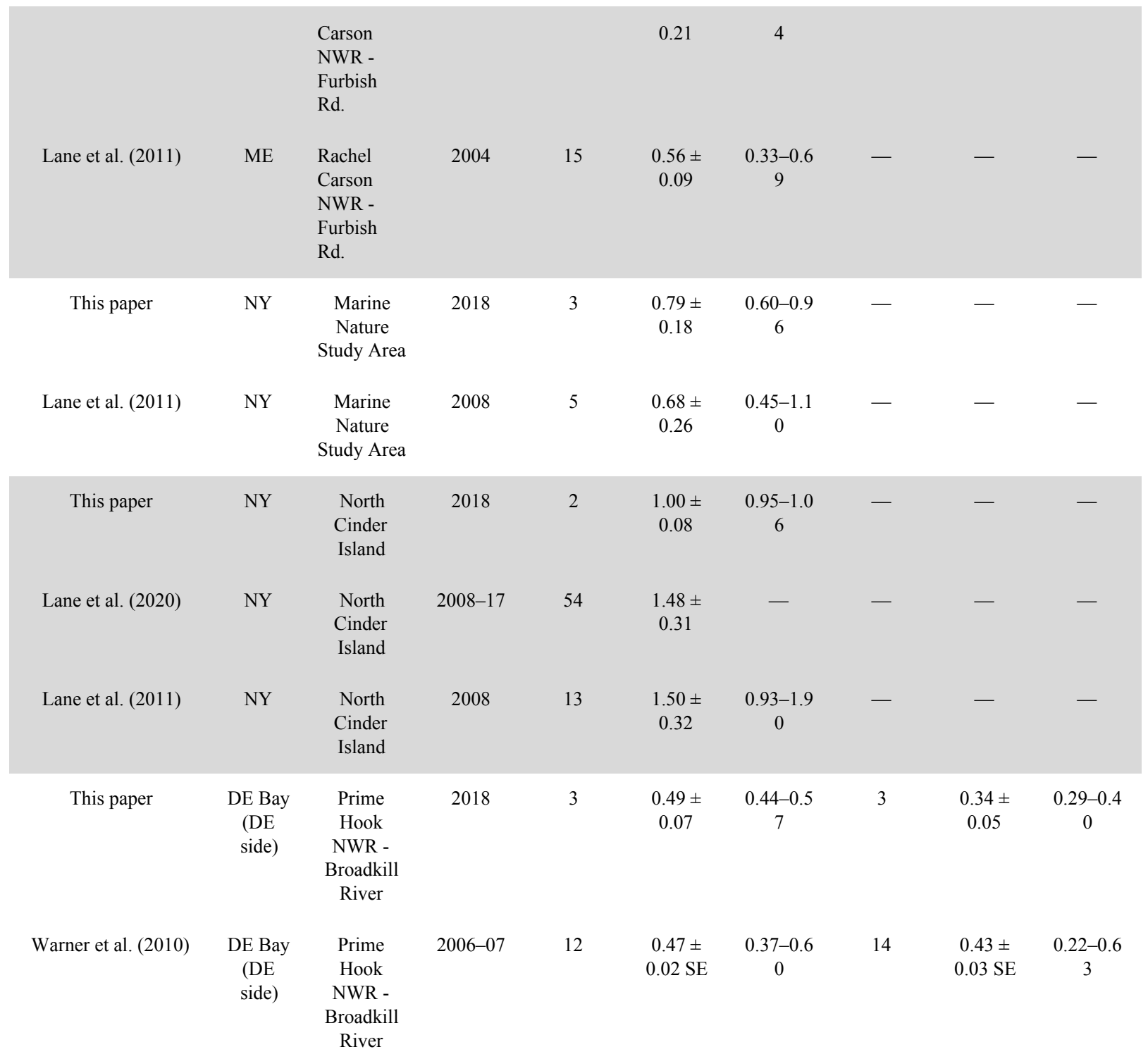




\section{Figures}
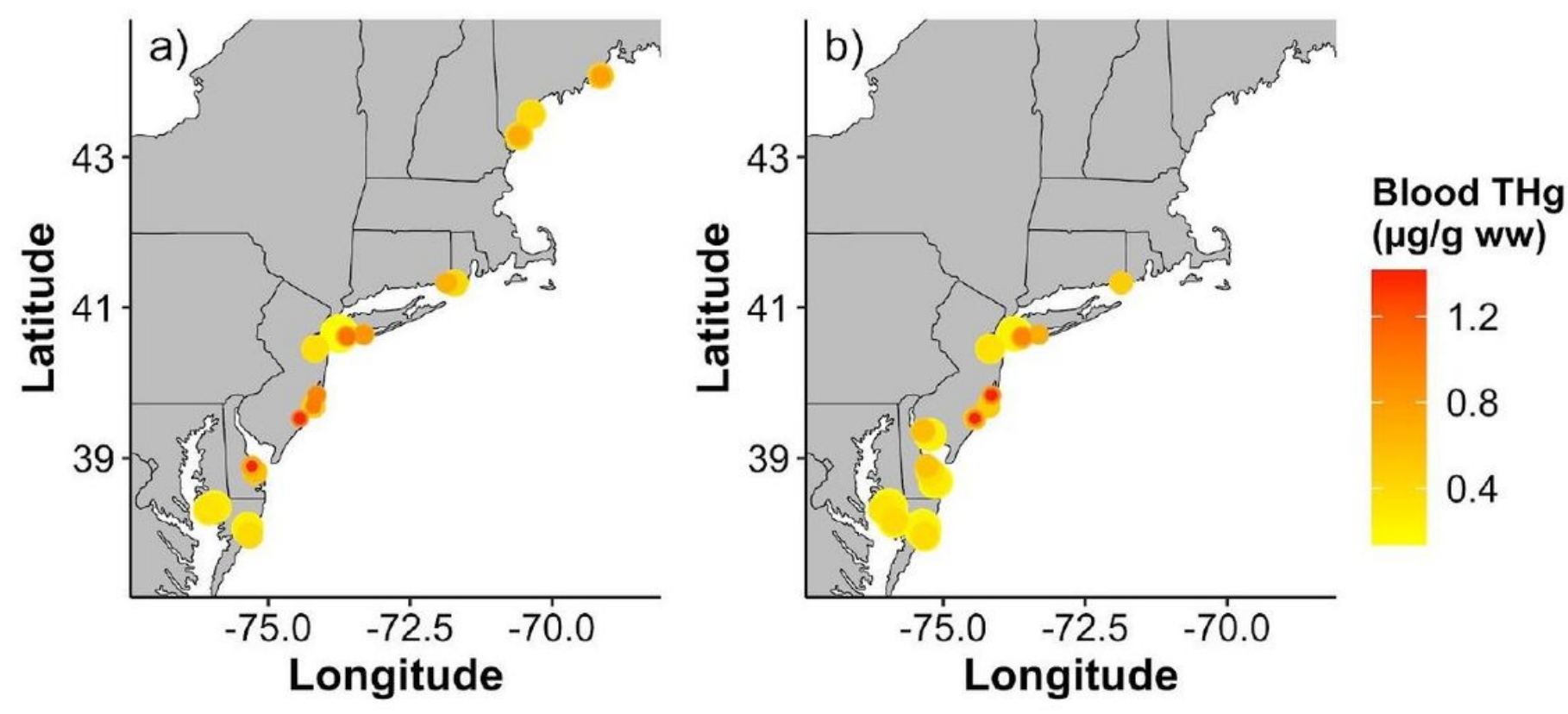

Figure 1

Map of blood THg concentrations ( $\mu \mathrm{g} / \mathrm{g} \mathrm{ww}$ ) of breeding a) saltmarsh sparrows and b) seaside sparrows for all sampling locations from Maine to Virginia, USA, June 1 to July 31, 2018 Note: The designations employed and the presentation of the material on this map do not imply the expression of any opinion whatsoever on the part of Research Square concerning the legal status of any country, territory, city or area or of its authorities, or concerning the delimitation of its frontiers or boundaries. This map has been provided by the authors. 


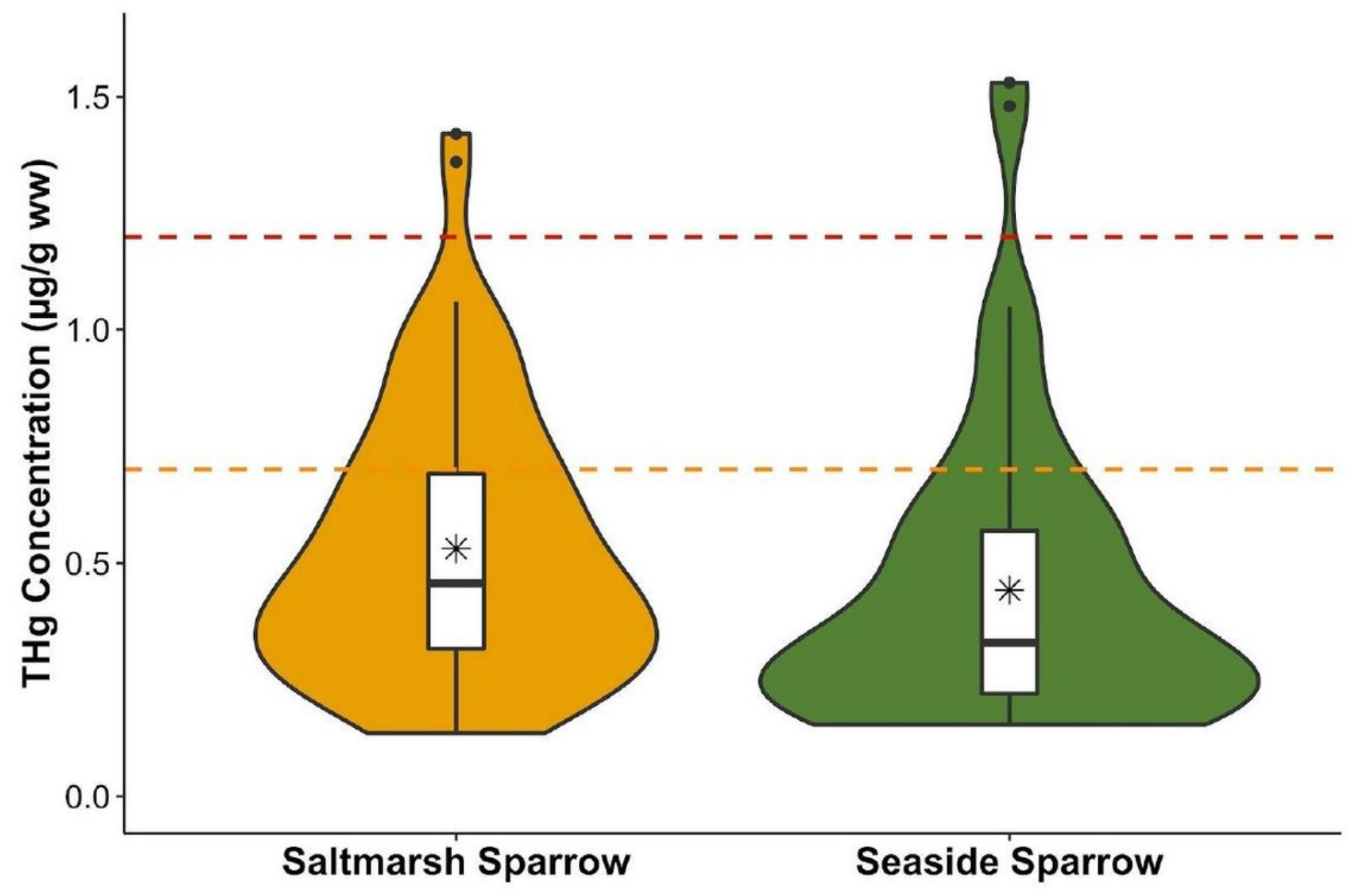

Figure 2

Blood THg concentrations ( $\mu \mathrm{g} / \mathrm{g}$ ww) of breeding tidal marsh sparrows from Maine to Virginia, USA, June 1 to July 31, 2018. The "violin" shapes represent the vertically-oriented distribution of THg concentrations per species. The boxplots display the outliers (dots), maximum and minimum concentration excluding the outliers (ends of whiskers), first and third quartile (central box), median (horizontal black line), and mean $\left({ }^{*}\right) \mathrm{THg}$ concentration per species. Dashed horizontal lines indicate the $0.7 \mu \mathrm{g} / \mathrm{g} \mathrm{ww} 10 \%$ effect concentration (EC10) and the $1.2 \mu \mathrm{g} / \mathrm{g}$ ww $20 \%$ effect concentration (EC20) defined by Jackson et al. (2011) 